\title{
Applications of Flow Cytometry to Hematopoietic Stem Cell Transplantation
}

\author{
Júlio C Voltarelli
}

Unidade de Transplante de Medula Óssea, Departamento de Clínica Médica, Faculdade de Medicina de Ribeirão Preto, Universidade de São Paulo, 14048-900 Ribeirão Preto, SP, Brasil and Dept. of Immunology, The Scripps

Research Institute, La Jolla, CA, USA

Applications of flow cytometry to clinical and experimental hematopoietic stem cell transplantation (HSCT) are discussed in this review covering the following topics: diagnosis and classification of lymphohematologic disorders, quantitation of hematopoietic progenitors in the graft, lymphohematopoietic reconstitution following HSCT and animal models of human HSCT. At the end, the utilization of flow cytometry in clinical HSCT by Brazilian transplant centers is briefly reviewed.

Key words: flow cytometry - bone marrow transplantation - stem cell transplantation

During the last two decades, hematopoietic stem cell transplantation (HSCT) became the most efficient modality of treatment for a variety of lymphohematopoietic neoplasms and for some solid tumors and non-malignant disorders (Thomas 1994). Considerable progress in the technology of HSTC have expanded its clinical application and improved its survival rate, leading to an exponential growth in the numbers of transplants performed and of transplantation centers in operation, including in our country. This progress also caused a great diversification of HSCT in addition to the conventional HLA-identical sibling bone marrow transplantation (BMT): autologous, family related unmatched, family unrelated matched or unmatched, cord blood and peripheral blood transplantation have been introduced to medical practice. In the future, advances in immunotherapy, genetic engineering and cell selection will certainly lead to much better results of HSCT in curing a variety of diseases with otherwise fatal course.

In 1984, the Seattle group, which pioneered the field of human bone marrow transplantation, published a short review on the application of flow cytometry to BMT (Martin et al. 1984). Presentation was restricted to quantitative assays to assess the efficiency of $\mathrm{T}$ cell depletion from the marrow graft in order to prevent graft-versus-host disease (GVHD), concluding that we have found flow microfluorometry to be an indispensable tool in

Financial support: Fapesp, CNPq, Fundherp and FaepaHCFMRPUSP.

E-mail: jcvoltar@scripps.edu or jcvoltar@fmrp.usp.br. Received 9 August 1999

Accepted 17 November 1999 the development of methods of removing $T$ cells from donor marrow. However, the prospective was that this application of flow microfluorometric technology to human marrow transplantation represents only one of several possible such applications. Flow microfluorometric technology will find utility in any situation requiring sensitive and specific methods for the identification of distinct cell populations in human bone marrow or blood.

In fact, two years later we disclosed in another review a broader range of applications of flow cytometry to BMT, including characterization of immunologic reconstitution, pathophysiologic and diagnostic investigation of GVHD, viral infections and minimal residual disease (Voltarelli \& Stites 1986). A Medline search of the literature from October 1981 through January 1999 produced more than 500 papers in this area. Most of them focus on the same above mentioned subjects, but there were significant advances also in the detection of engraftment, of alloimunization against blood cells, in the investigation of graft-versus-leukemia effect, in the quantitation of HSC and, more recently, in animal models of human transplantation and in gene therapy. Thus, technological improvements in equipments, methods, reagents and analytical software played a major role in the progress made in this area.

The purpose of this review is to summarize the participation of flow cytometry technology in the progress of HSCT during the last five years both at the clinical and experimental levels highlighting the contribution of our group to the field.

\section{CLINICAL APPLICATIONS OF FLOW CYTOMETRY TO STEM CELL TRANSPLANTATION}

In this section, current and potential utilization of flow cytometry to the management of HSCT candidates or patients will be discussed. 
Diagnosis and classification of lymphohematologic disorders - Immunophenotypic characterization of lymphohematopoietic neoplasms was one of the first applications of flow cytometry to clinical medicine improving the precise diagnosis and staging of those diseases as well as the detection of their persistance or recurrence after HSCT (Jennings \& Foon 1997). Other papers in this volume will certainly cover the subject. In Brazil, a survey of 225 patients with acute lymphoblastic leukemia (ALL) showed a higher frequency of the B-mature phenotype in the white population compared to developed countries. In the non-white population, there was a lower incidence of ALL in childhood, particularly of the common ALL (cALL) subtype, resembling the situation in nonwhite Americans before the 1970s and of British and American whites at the beginning of the century (Rego et al. 1996). In addition, among 117 patients with cALL, a high frequency of the $\mathrm{CD} 19^{+} \mathrm{CD} 10^{+ \text {strong }}$ phenotype was observed in both children and adults and overexpression of CD10 and/or CD19 occurred in $42 \%$ of the cases which may be helpful for diagnosis or detection of minimal residual disease (Rego et al. 1999). On the other hand, children up to four years of age have more than $65 \%$ of B cells in the lymphocyte window in the bone marrow. Most of these cells have the immature phenotype CD19+CD10+ which may be confounded with leukemic blasts (Rego et al. 1998a).

Simultaneous analysis of three or four antigens on the cell surface, employing one or two laser beams, and the quantitative evaluation of antigen density were two significant technological advances in the diagnosis of hematological malignancies. Thus, multiparameter flow cytometry was succesfully employed to detect occult B cell malignancies in cytopenic patients (Wells et al. 1998a), to characterize acute myeloid leukemia with minimal differentiation (AML-M0) (Cohen et al. 1998) and to differentiate normal from leukemic blast cells after bone marrow transplantation (Wells et al. 1998b). Distinction between normal and leukemic cells can also be accomplished by quantitative flow cytometry, at least in ALL (Farahat et al. 1998, Rego et al. 1998b) and by intracellular markers in AML (Konikova et al. 1998). However, most efficient methods for detection of minimal residual disease combine fluorescent activated cell sorting with molecular methods such as in situ hybridization (Cotteret et al. 1998) or reverse transcriptasepolymerase chain reaction (RT-PCR) (Rasmussen et al. 1998).

Using multiparametric cytometry and well defined study protocols, the Salamanca group made significant contributions to the detection of mini- mal residual disease in hematologic neoplasms. A variety of diseases were studied, including ALL (Ciudad et al. 1998), AML (Macedo et al. 1995 San Miguel et al. 1997), chronic lymphocytic leukemia (Tabernero et al. 1995), mast cell leukemia (Cervero et al. 1999) and multiple myeloma (Ocqueteau et al. 1996).

In addition, as we did earlier (Falcão et al. 1992), unusual NK-associated malignancies continue to be described with the help of flow cytometry (Drenou et al. 1997, Suzuki et al. 1997). The case we reported was a CD3+CD16+TCR $\gamma /$ $\delta+\mathrm{T}$ cell leukemia with functional NK activity. The more recent ones were, respectively, two CD3CD56+ non-Hodgkin's lymphomas with no NK activity but aggresssive behaviour related to a multi drug resistant (MDR) phenotype, and seven CD7+CD56+ leukemias which could represent an yet unrecognized common myeloid/NK primitive precursor.

Characterization and differential diagnosis of many nonmalignant disorders treatable by HSCT has also benefited from recent advances in the detection of specific disease markers by flow cytometry. Examples of those diseases are paroxysmal nocturnal hemoglobinuria (Doukas et al. 1998), Wiskott Aldrich syndrome (Yamada et al. 1999), leukocyte adhesion deficiency (Thomas et al. 1995), MHC class II deficiency (Klein et al. 1995), DiGeorge Syndrome (Matsumoto et al. 1998) and chronic granulomatous disease (Atkinson et al. 1997).

Quantitation of hematopoietic progenitors in the graft - One of the most significant breakthroughs for the success of HSCT was the phenotypic and functional characterization of the primitive cells responsible for lymphohematopoietic reconstitution in transplanted patients (Baum et al. 1992). Discovery of the CD34 molecule present on many of these cells caused an explosion of new data on the mechanisms of normal, pathological and transplanted hematopoiesis. It also provided a very powerful tool to evaluate the engraftment requirements and repopulating potential of different types of grafts now employed in clinical HSCT. More recently, however, a CD34neg human stem cell was also described (Bhatia et al. 1998).

With the exception of transfusion sensitized aplastic anemia patients, HLA-identical sibling BMT or PBSCT usually show very high engraftment rates. In other types of transplants, such as allogeneic HLA-mismatched, unrelated, T cell depleted, from cord blood and, particularly, in autologous transplantation, the numbers and function of HSC in the graft usually are more critical to achieve engraftment. Thus, qualitative and quantitative evaluation of HSC present in the graft be- 
came a reliable predictor of engraftment in many modalities of HSCT and have been extensively used to select the best timing to harvest the cells to be transplanted. A minimum cell dose of $0.75 \mathrm{x}$ $10^{6} \mathrm{CD} 34+/ \mathrm{kg}$ was found to be necessary for engraftment of autologous PBSCT and this dose could be achieved when the absolute CD34+ cell count was $>5 / \mu \mathrm{l}$ in the peripheral blood (Perez Simon et al. 1998). Other studies, however, found higher thresholds for CD34+ cell dose (2 to $2.5 \mathrm{x}$ $10^{6} / \mathrm{kg}$ ) and for absolute CD34+ cell counts in peripheral blood (10/ $\mu$ l) (Schots et al. 1996, Dansey et al. 1998). For unmanipulated allogeneic PBSCT, the threshold cell dose was found to be $2.5 \times 10^{6}$ CD34 + cells $/ \mathrm{kg}$ (Korbling et al. 1995) while for T cell-depleted marrow transplants it was $10^{6} \mathrm{CD} 34+/$ $\mathrm{kg}$ (Mavroudis et al. 1996). Nucleated cell dose and CD34+ cell dose are major determinants in engraftment of cord blood transplants (reviewed by Cairo \& Wagner 1997). However, the threshold number of CD34+ cells needed for engraftment could not be determined in a large cooperative study of cord blood transplantation in Europe (Eurocord) due to problems in the standardization of HSC quantitation (Gluckman et al. 1998).

Several recent studies assessed the content, phenotype and function of HSC from different transplantable tissues using flow cytometry. Compared to peripheral blood, cord blood contains a higher proportion of primitive HSC (CD34+HLADR-) and of immature and non-functional T cells (Cairo \& Wagner 1997, Madrigal et al. 1997, Dimitriou et al. 1998). These features suggest that cord blood cells may be more efficient and cause less GVHD than other sources of HSCT. On the other hand, bone marrow cells aspirated from iliac crests contain a high proportion of HSC with B cell markers while most HSC from peripheral blood mobilized with either high dose chemotherapy or myeloid growth factors have myeloid markers (Fritsch et al. 1996). This difference may explain the faster myeloid engraftment after mobilized PBSCT compared to non-mobilized BMT (Talmadge et al. 1997, Vigorito et al. 1998). Cadaveric vertebral bodies have also been used in some protocols to promote hematopoietic reconstitution or to increase donor cell chimerism in solid organ transplantation. Vertebral bodies have more nucleated cells than bone marrow aspirated from iliac crests of normal allogeneic donors and equivalent content of HSC, as evaluated by clonogenic assays or flow cytometry (Rybka et al. 1995). Finally, the content of megacaryocityic precursors (CD34+/ $\mathrm{CD} 61+)$ in the graft could be correlated with time of platelet engraftment in patients submitted either to allogeneic (Bojko et al. 1998) or to autologous (Johnsen et al. 1998) peripheral blood HSCT.
The very low frequency and unremarkable morphologic characteristics of HSCT in various tissues make it very difficult to precisely quantify these cells. Many factors interfere with their enumeration, such as sample storage (Gutensohn et al. 1996), cell washing (Menendez et al. 1998), red cell lysing method (Cassens et al. 1998) and the quality of the monoclonal antibody used (Macey et al. 1997). In fact, the latter and other reports have shown that mAbs to class II and III epitopes of the CD34 molecules are less affected by lysis and fixation procedures than class I antibodies. Several protocols have been devised to standardize the flow cytometric enumeration of HSC and to minimize artifacts and count errors. Recent comparisons between most popular protocols showed superiority of a volumetric method employing reference beads over the International Society of Hemotherapy and Graft Engineering (ISHAGE) four-parameter methodology (Leuner et al. 1998) and over institutional in-house methods when CD34 cell counts are very high (Olivero et al. 1999).

Fewer studies have investigated functional aspects of HSC containing transplants by flow cytometry. Chalmers et al. (1998) showed that cord blood $\mathrm{T}$ lymphocytes produced less intracellular proinflammatory cytokines (mainly IFN- $\gamma$ and TNF-a) than peripheral blood lymphocytes. In addition, most cytokine producing cells in cord blood were naive $\mathrm{T}$ helper cells (CD4+RA+) while in peripheral blood they were both $\mathrm{T}$ helper (CD4+RO+) and $\mathrm{T}$ cytotoxic cells (CD8+RO+) memory cells. These results could explain in part the lower incidence of GVHD after cord blood transplantation. In another study, the rate of the rhodamine-123 vital dye efflux from CD34+ cells was correlated with cell imaturity and with repopulating capacity of human HSC (Uchida et al. 1996). The most primitive CD34+Thy1+Lin- self-renewing cells had low or medium levels of Rh-123 retention while CD34+ cells with high level of dye retention lacked long-term engraftment potential.

Lymphohematopoietic reconstitution following HSCT - Immunologic reconstitution after HSCT is a very complex and important series of phenomena which could not be properly investigated until the advent of flow cytometry. Low numbers of circulating cells with exquisite phenotypes and multiple functional abnormalities seen in the posttransplant period are very difficult to characterize with conventional fluorescence microscopy or cell culture based immune function methods. While immune reconstitution followup is not routinely performed after HSCT, information provided by its investigation has great predictive value for infection, GVHD, relapse and immunoprofilaxis. 
On the other hand, hematopoietic engraftment following HSCT is routinely monitored by rising blood cell counts following the pancytopenic state caused by the conditioning regimen. However, fluoro-cytometric techniques may detect early and more subtle signs of myeloid engraftment and may help to distinguish between several types and degrees of chimerism that may occur in the event of graft failure or recurrent disease. We have found that graft failure after allogeneic bone marrow transplantation is associated with defective expression of IL-2R (CD25) on activated CD8 T cells (Voltarelli et al. 1989) and that a mild T cell depletion with anti-CD6 mAb may explain its low rate of graft failure compared to other methods (Voltarelli et al. 1990). More recently, fluorocytometric reticulocyte counts detect engraftment earlier than neutrophil counts (SMSGHR 1994, Greinix et al. 1994) and a panel of Mabs against erythrocyte antigens could be used to uncover both early engraftment and chimeric states after HSCT (Blanchard et al. 1995, Nelson et al. 1996, Hendriks et al. 1997). Finally, monitoring CD34+ cells after HSCT showed that their numbers correlated with platelet recovery (Gebauer et al. 1996) and that donor CD34+/HLA-DR- capable of long term hematopoietic repopulation are present in the $\mathrm{BM}$ of patients receiving allogeneic PBSCT (Briones et al. 1998).

The first in depth fluorocytometric analysis of recovering lymphocyte subpopulations after HSCT was published fifteen years ago (Ault et al. 1985). They followed four patients submitted to BMT (three allogeneic $\mathrm{T}$ cell-depleted and one syngeneic) during the first 90 days after transplantation and found few mature $\mathrm{T}$ cells and large numbers of functional NK cells and non-functional CD5+ $B$ cells. These findings were later confirmed by other studies (reviewed by Voltarelli \& Stites 1986 and by Lum 1990). More recently, immunologic reconstitution has been investigated in different types of HSCT. Thus, Small et al. (1999) showed that adult patients submitted to $\mathrm{T}$ cell-depleted unrelated BMT experience prolonged and profound $\mathrm{T}$ cell immunodeficiency compared to pediatric recipients of unrelated BMT and adults after related BMT. The former patients had an increased risk of severe opportunistic infections which correlated negatively with the rate of recovery of CD4 $\mathrm{T}$ cells. This correlation was also observed by Trenschel et al. (1998) comparing related and unrelated allogeneic BMT with peripheral blood HSCT which showed faster myeloid and CD4 reconstitution and lower frequency of opportunistic infections. In other set of studies, human dendritic cells identified by the Mab CMRF44 were found to be low in the peripheral blood of patients sub- mitted to PBSC harvesting for allogeneic or autologous HSCT and in patients with acute GVHD (Fearnley et al. 1999). In this condition CD4 cells were activated (HLA-DR+Ox40+) and displayed Th2 phenotype (CD30+/CD7-) (Grimley et al. 1999) while eosinophils showed signs of selective activation as judged by the expression of the IL2$\mathrm{R} \alpha$ (CD25) (Rumi et al. 1998) . Finally, the presence of residual thymic function was shown to be required for the reconstitution of the $\mathrm{CD} 4 \mathrm{~T}$ helper subset, but not for the CD8 T cytotoxic/suppressor subset (Heitger et al. 1997). On the other hand, in autologous BMT, hematopoietic growth factors favored the recovery of activated CD8 T cells (GM$\mathrm{CSF}$ ) or of memory and naive CD4 T cells (GCSF) (San Miguel et al. 1996). In addition, autologous transplantation of FACS-sorted CD34+ cells from peripheral blood resulted in delayed immune reconstitution, decreased diversity of V $\beta$ TCR expression in all patients and an increase of TCR $\gamma \delta$ T cells and of CD5+ B cells in one third of patients compared to unmanipulated grafts (Bomberger et al. 1998). Immune recovery after autologous transplantation was reviewed by Guillaume et al. (1998).

\section{FUTURE AND POTENTIAL APPLICATIONS}

In the future, flow cytometric methods will certainly replace much of the current technology employed in the practice of human HSCT. New areas of development include detection of cytomegalovirus infection (Honda et al. 1997, Imbert-Marcille et al. 1997), of neutrophil (Maher \& Hartman 1993) or platelet (Kohler et al. 1996) alloimmunization, documentation of chimerism by fluorescence in situ hybridization (Arkesteijn et al. 1995, van Tol et al. 1998), functional activation of T cells detected by intracellular cytokine production (Tarantolo et al. 1998) and selection of HSC or immunocompetent cells for transplantation or gene therapy (Korbling et al. 1994, Sasaki et al. 1995). In fact, both the human multidrug resistance (MDR) gene transfected to HSC (Richardson \& Bank 1995) and the herpes simplex virus-thymidine kinase gene transfected to human T cells (Bonini et al. 1997) express cell surface proteins (a MDR associated pglycoprotein and the low affinity receptor for nerve growth factor respectively) that can be detected and selected by flow cytometry. In addition, FACS selection of T cells containing TCR-V $\beta$ families which lead to GVHD or GVL (Epperson et al. 1999) or of $\mathrm{T}$ cells which bind to MHC-leukemic peptide tetramers (Dunbar et al. 1998) may be used in the future as immunotherapeutic approaches combined to HSCT. Finally, cell cycle analysis of normal stem cells (Gothot et al. 1998) or neoplastic tissues (Orfao et al. 1994) by DNA staining may also be helpful for engraftment or prognosis studies after HSCT. 
APPLICATIONS OF FLOW CYTOMETRY TO ANIMAL MODELS OF HUMAN STEM CELL TRANSPLANTATION

Over the last years, there was considerable progress towards the development of animal models to support human stem cell engraftment. Most of these models involve mutant/inbred strains of immunodeficient mice which allow long term proliferation and differentiation of primitive human hematopoietic stem cells from different sources. They provide unvaluable research tools not only to dissect the physiology of human hematopoiesis but also to investigate multiple aspects of hematopoiesis-based diseases, including the effects of genetic manipulation on the treatment of these diseases. The contribution of flow cytometry for the establishment and investigation of animal models of human hematopoiesis is outlined in this section.

Early attempts to transplant human bone marrow cells into irradiated mice, into mice deprived of $\mathrm{T}$ cells (with the nude mutation) or into fetal sheep resulted in low levels of human stem cell engraftment. Other immunodeficient murine models such as beige, xid (X-linked immunodeficient) and Ragl or 2 (deficient in the recombination activating gene-1 or 2) were not successful as well and the most suitable host was found to be mice homozygous for the scid mutation (reviewed by Greiner et al. 1998). The scid mutation was first described in 1983 in the C.B-17 strain of mice which lack both cellular and humoral immunity in the homozygous state. The first reports of engraftment of human hematopoietic cells in scid mice appeared in 1988, including intraperitoneal transplantation of PBL (Mosier et al. 1988) and transplantation of fetal bone marrow or fetal liver with or without fetal thymus fragments under the renal capsule of unirradiated recipients (McCune et al. 1988) followed by intravenous transplantation of bone marrow into irradiated animals (Lapidot et al. 1992). Models of hematopoietic engraftment employing human fetal tissues (the $S C I D-h u$ mice) have ethical and availability limitations while in the $h u$-SCID model with postnatal tissues the engraftment levels of human cells are low (0.5-5\% of the scid marrow). This is due to the lack of species cross-reactivity of growth factors and cytokines required for human stem cells and also to residual host innate immunity present in the scid mice. These animals have elevated levels of hemolytic complement and NK activity and normal granulocyte and macrophage function which interfere with the engraftment of human hematopoietic cells. Backcrossing the C.B-17-scid mice with several inbred strains carrying specific defects in innate immunity led to the generation of the nonobese diabetic (NOD)-scid mice which exhibit multiple defects in innate immunty but do not develop diabetes. In this NOD-scid strain the levels of engraftment of human stem cells from peripheral blood or spleen were always 5- to 10-fold higher than in any of the other scid strains examined and it became the most useful animal model of human hematopoiesis and HSCT available. Additional modifications of the NOD/scid model with the introduction of the $\beta 2$-microglobulin deficiency and consequent absence of MHC class class I further increased the level of human cell engraftment and allowed the development of $\mathrm{T}$ cells with normal CD4:CD8 ratio (Christianson et al. 1997).

Phenotypic characteristics of various sources of human lymphohematopoietic cells engrafting NOD-scid mice have been investigated. Initially, nonmobilized peripheral blood or spleen cells were injected intraperitoneally into unirradiated scid mice (Greiner et al. 1995). As mentioned earlier, the degree of engraftment was higher in NOD-scid than in C.B-17-scid and it was similar for PBL and spleen transplants; most circulating or splenic cells grafted in the mouse were CD4 or CD8 T cells, less than 5\% expressed monocyte or B cell markers. When selected CD34+ cells mobilized from the peripheral blood by G-CSF were administered intravenously to irradiated NOD-scid mice, engraftement of human cells could be detected up to 6.5 months after transplantation and comprised as high as $96 \%$ of bone marrow cells (van der Loo et al. 1998). The phenotypes of these cells differ significantly between different organs of the host animal: mature $\mathrm{CD} 20+10$ - B cells predominate in the spleen whereas myeloid cells (CD33+HLA$\mathrm{DR}+$ ) predominate in the $\mathrm{BM}$, and the thymus contained a large percentage of human immature $\mathrm{T}$ cells $(\mathrm{CD} 4+\mathrm{CD} 8+$ and $\mathrm{CD} 8+\mathrm{CD} 7+)$. However, other studies showed that $\mathrm{T}$ cells developed in NOD/SCID mice transplanted with the more primitive CD34neg SC and not with the CD34+ ones (Bhatia et al. 1998). Human bone marrow cells capable of repopulating NOD-scid mice are present in the CD34+38- fraction and generated significant numbers of human CD34+38- cells in the marrow of the animals and multiple lineages of human cells (Larochelle et al. 1996).

Most transplantation models of normal human stem cells into scid mice involved the use of cord blood cells. These studies showed that, like the BM, the long term repopulating cell is also present in the CD34+38-fraction and that predominant cell generated in the marrow and in peripheral tissues are B cells, expanded from the CD34+CD19+ precursor compartment (Pflumio et al. 1996, Hogan et al. 1997). Culture of purified CD34+CD38- cord blood cells with bone marrow stromal cells reduced 
significantly the in vivo repopulating capacity of transplanted cells (Gan et al. 1997) while the expansion of those cells with growth factors (IL-3, IL-6 and stem cell factor) markedly delayed lymphohematopoietic engraftment (Guenechea et al. 1999). Finally, repopulation of NOD-scid mice with CD34+ purified cord blood cells was found to be dependent on the expression of the chemokine receptor CXCR4 which binds to the stromal cellderived factor-1 (SDF-1) (Peled et al. 1999).

The scid mouse model has also been extensively used to investigate the biology and treatment alternatives for human leukemias (reviewed by Uckun 1996) and other hematological malignancies such as multiple myeloma and lymphomas. Flow cytometric methods were very instrumental in these investigations, including the few studies involving infusion of immunocompetent cells from allogeneic or autologous donors. Detection of engraftment of human malignant cells in the animal host can be achieved by a panel of monoclonal antibodies similar to that used for diagnosis of the disease in humans (Baersch et al. 1997) or to characterize human tumor cell lines as in multiple myeloma (Rebouissou et al. 1998). On the other hand, infusion of in vitro antigen stimulated cytotoxic $\mathrm{T}$ cells caused regression of human autologous EBVinduced B cell lymphoproliferative disease (Lacerda et al. 1996) or of allogeneic acute myeloid leukemia (Warren et al. 1997) or acute lymphoblastic leukemia (Nijmeier et al. 1998).
Protocols of gene transfection of human HSC which could be employed in clinical transplantation (reviewed by Richter 1997, and by Brenner et al. 1998) have also benefited from the convenience and quickness of fluorocytometric technology. Most of these protocols use oncoretroviral vectors such as the murine leukemia virus which integrates into the chromosomes of replicating target cells resulting in stable expression of transgenes. However, few studies have succeeded in transducing retroviral vectors to human stem cells (Yurasov et al. 1997, Cheng et al. 1998, Rill et al. 1997) possibly due to the quiescent nature of human HSC and the requirement of cell division for retroviral integration. Very recently, human resting CD34+ cells were transduced with an HIV-derived vector and were able to repopulate NOD-scid mice (Miyoshi et al. 1999). Levels of engraftment, detected in the FACS by the expression of the green fluorescence protein coupled to the viral vector, were as high as $27 \%$ of human CD45+ cells in the BM (Figure), $22 \%$ in the spleen and $20 \%$ in the peripheral blood. The use of this new class of vectors provide an innovative approach to study hematopoiesis and to human gene therapy if the safety issues are properly addressed.

\section{FLOW CYTOMETRY APLLIED TO HSCT IN BRAZIL}

In a recent survey among 12 stem cell transplant centers active in Brazil, we found that the majority of them (8) use a flow cytometer for clini-
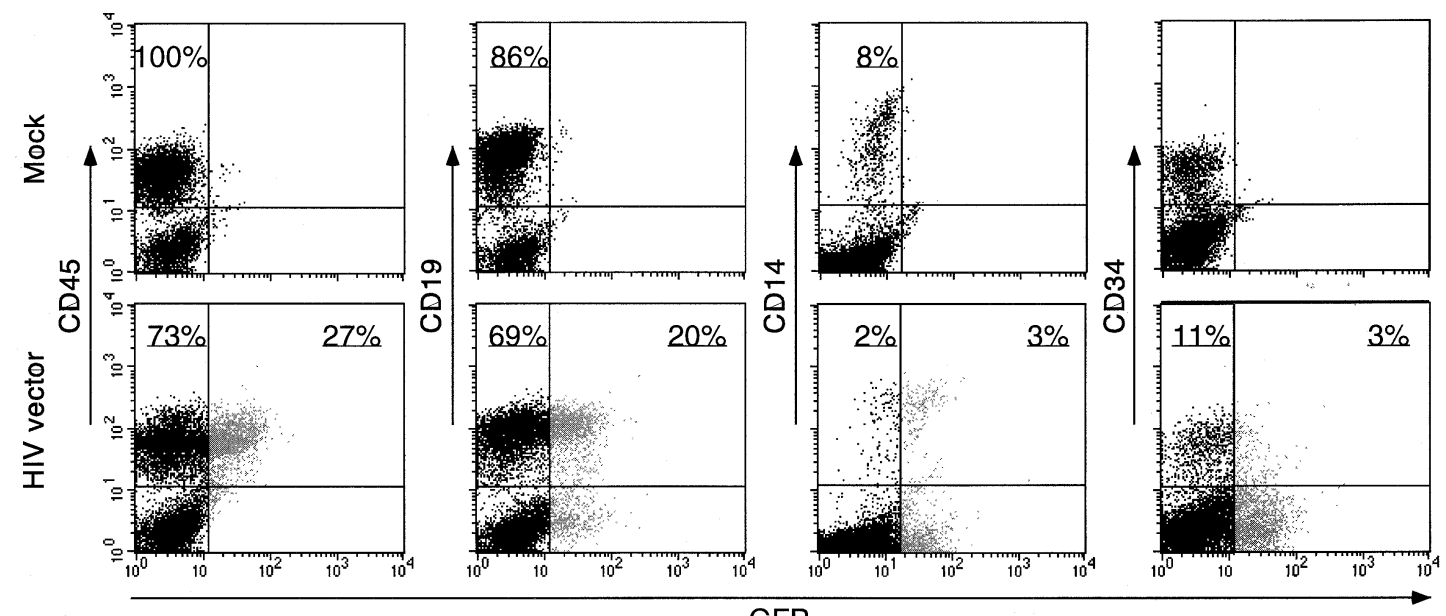

Green fluorescent protein expression in human lymphoid and myeloid cells from the bone marrow of NOD/SCID mice transplanted with HIV vector-transduced CD34+ cells. Representative flow cytometric analysis of bone marrow cells from mice transplanted with mock- or HIV vector-transduced CD34+ cells are shown. Both mice had similar levels of human cell engraftment. Presented values are as the percentages of total human cells. Reprinted from Miyoshi et al. Science 283: 682-686, 1999. Copyright 1999 American Association for the Advancement of Science. 
cal or investigation purposes. Four centers have equipments restricted to cell analysis and in other four centers equipments were also capable of cell sorting, but they are used mainly for analysis. Most centers utilize flow cytometry to quantitate stem cells contained in autografts or $\mathrm{T}$ cells present in donor lymphocyte infusions and in investigations related to stem cell mobilization or immune reconstitution (Souza et al. 1994, Diamond et al. 1995, Vigorito et al. 1998). In our center, we have been using fluorocytometric methods to compare cell content between different types of grafts (bone marrow, peripheral blood and cord blood) (Lemos et al. unpublished), to assess alloimmunization against neutrophils (Corsini et al. unpublished) or platelets (Palma et al. unpublished) and to characterize the immune response of donor lymphocyte infusions (DLI) against chronic myelogenous leukemia relapsed after allogeneic BMT (Castro et al. unpublished). In a preliminary analysis of this latter study, we found that some patients receiving DLI show signs of lymphocyte activation in the peripheral blood, specially upregulation of HLA class II molecules in various lymphocyte subsets, which correlated with functional assays of allostimulation. These findings are particularly relevant given the reduced expression of HLA class II molecules on target (Dermime et al. 1997) and effector (Castro et al. 1999) cells from patients with leukemia which seem to impair their immune response against tumor cells.

\section{ACKNOWLEDGMENTS}

To Dr Bruce Torbett for reviewing the manuscript and for providing the Figure.

\section{REFERENCES}

Arkesteijn GJ, Erpelinck SL, Martens AC, Hagenbeek A 1995. Chromosome specific DNA hybridization in suspension for flow cytometric detection of chimerism in bone marrow transplantation. Cytometry 19: 353-360.

Atkinson TP, Bonitatibus GM, Berkov RL 1997. Chronic granulomatous disease in two children with recurrent infections: Family studies using dihydrorhodamine-based flow cytometry. J Pediatr 130: 488-491.

Ault KA, Antin JH, Ginsburg D, Orkin SH, Rappeport JM, Keohan ML, Martin P, Smith BR 1985. Phenotype of recovering lymphoid cell populations after marrow transplantation. J Exp Med 161: 1483-1502.

Baersch G, Mollers T, Hotte A, Dockhorn-Dworniczak B, Rube C, Ritter J, Jurgens H, Vormoor J 1997. Good engraftment of B cell precursors ALL in NODSCID mice. Klin Pediatr 209: 178-185.

Baum CM, Weissman IL, Tsukamoto AS, Buckle AM, Peault B 1992. Isolation of a candidate human hematopoietic stem cell population. Proc Natl Acad Sci 89: 2804-2808.
Bhatia M, Bonnet D, Murdoch B, Gan OI, Dick JE 1998. A newly discovered class of human hematopoietic cells with SCID-repopulating activity. Nat Med 4: 1038-1045.

Blanchard D, Bruneau V, Bernard D, Germond-Arnoult F, Gourbil A, David B, Muller JY 1995. Flow cytometric analysis of dual red cell populations after bone marrow transplantation. Br J Haematol 89: 741-747.

Bojko P, Hester JP, Durett AG, Maadani F, Korbling M, Champlin RE 1998. Identification of megacaryocyte precursors in peripheral blood stem cell collections from normal donors. J Clin Apheresis 13: 7-15.

Bomberger C, Singh-Jairam M, Rodey G, Guerriero A, Yeager AM, Fleming WH, Holland HK, Waller EK 1998. Lymphoid reconstitution after autologous PBSC transplantation with FACS-sorted CD34+ hematopoietic progenitors. Blood 19: 2588-2600.

Bonini C, Ferrari G, Verzeletti S, Savida P, Zappone E, Ruggieri L, Ponzoni M, Rossini S, Mavilio F, Traversari C, Bordignon C 1997. HSV-TK gene transfer into donor lymphocytes for control of allogeneic graft-versus-leukemia. Science 276: 17191724.

Brenner MK, Heslop HE, Rooney CM 1998. Gene and cell transfer for specific immunotherapy. Vox Sang 74 (Suppl. 2): 87-90.

Briones D, Urbano-Ispizua A, Orfao A, Marin P, Sierra J, Rovira M, Carreras E, Rozman C, Montserrat E 1998. Demonstration of donor origin of CD34+ HAL-DR- bone marrow cells after allogeneic peripheral blood transplantation with a long followup. Bone Marrow Transplant 21: 189-194.

Cairo MS, Wagner JE 1997. Placental and/or umbilical cord blood: na alternative source of hematopoietic stem cells for transplantation. Blood 90: 4665-4678.

Cassens U, Gutensonh K, Garritsen H, Kelsch R, Kuehnl P, Sibrowski W 1998. The influence of different erythrocyte lysing procedures on flow cytometric determination of CD34+ cells in umbilical cord blood transplants. Transfus Med 8: 111-118.

Castro FA, Paula Santos CM, Voltarelli JC 1999. Stimulation of HLA-DR antigen expression in acute and chronic leukemias. Cancer Research Therapy and Control, in press.

Cervero C, Escribano L, San Miguel JF, Diaz-Augustin B, Bravo P, Villarubia J, Garcia Sanz R, Velasco JL, Herrera P, Vargas M, Gonzalez M, Navarro Jl, Orfao 1999. Expression of $\mathrm{Bcl}-2$ by human bone marrow mast cells and its overexpression in mast cell leukemia. Am J Hematol 60: 191-195.

Chalmers IM, Janossy G, Contreras M, Navarette C 1998. Intracellular cytokine profile of cord and adult blood lymphocytes. Blood 92: 11-18.

Cheng L, Du C, Lavau C, Chen S, Tong J, Chen BP, Scollay R, Hawley RG, Hill B 1998. Sustained gene expression in retrovirally transduced, engrafting human hematopoietic stem cells and their lymphomyeloid progeny. Blood 92: 83-92.

Christianson SW, Greiner DL, Hesselton RA, Left JH, Wagar EJ, Schweitzer IB, Rajan TV, Gott B, Roopenian DC, Shultz LD 1997. Enhanced CD4+ T 
cell engraftment in beta2-microglobulin-deficient NOD SCID mice. J Immunol 158: 3578-3586.

Ciudad J, San Miguel JF, Lopez-Berges MC, Vidriales B, Valverde B, Ocqueteau M, Mateos G, Caballero MD, Hernandez J, Moro MJ, Mateos MV, Orfao A 1998. Prognostic value of immunophenotypic detection of minimal residual disease in acute lymphoblastic leukemia. J Clin Oncol 16: 3774-3781.

Cohen PL, Hoyer JD, Kurtin PJ, Dewald GW, Hanson CA 1998. Acute myeloid leukemia with minimal differentiation. A multiple parameter study. Am J Clin Pathol 109: 32-38.

Cotteret S, Belloc F, Boiron JM, Bilhou-Nabera C, Dumain P, Boyer C, Lacombe F, Reiffers J, Bernard $\mathrm{P}$ 1998. Fluorescent in situ hybridization on flowsorted cells as a tool for evaluating minimal residual disease or chimerism after allogeneic bone marrow transplantation. Cytometry 34: 216-222.

Dansey R, Zielinsky I, Klein J, Karanes C, Abella S, Carrion R, Du W, Cassells L, Peters W, Baynes R 1998. Optimization of peripheral blood stem cell collections using peripheral blood CD34 levels and routine high volume apheresis. Blood 92 (Suppl.1): 124a.

Dermime S, Mavroudis D, Jiang YZ, Hensel N, Molldrem J, Barrett AJ 1997. Immune scape from a graft-versus-leukemia effect may play a role in the relapse of myeloid leukemias following allogeneic bone marrow transplantation. Bone Marrow Transplant 19: 989-999.

Diamond HR, Souza MH, Bouzas LF, Tabak DG, Campos MM, Rumjanek VM 1995. Deficit of T-cell recovery after allogeneic bone marrow transplantation in chronic myeloid leukemia patients. Anticancer Res 15: 1553-1560.

Dimitriou H, Matsouka C, Perdikoyanni C, Stiakaki E, Bolonaki I, Lydaki E, Koumantakis E, Kalmanti M 1998. Phenotypic characteristics of cord blood hematopoietic cells. Leuk Res 22: 755-758.

Doukas MA, Fleming D, Jennings D 1998. Identical twin marrow transplantation for venous thrombosis in paroxismal nocturnal hemoglobinuria; long term complete remission as assessed by flow cytometry. Bone Marrow Transplant 22: 717-721.

Drenou B, Lamy T, Amiot L, Fardel O, CauletMaugendre S, Sasportes M, Diebold J, Le Prise PY, Fauchet R 1997. CD3-CD56+ non-Hogkin's lymphomas with an aggressive behaviour related to multidrug resistance. Blood 89: 2966-2974.

Dunbar PR, Ogg GS, Chen J, Rust N, van der Bruggen P, Cerundolo V 1998. Direct isolation, phenotyping and cloning of low frequency antigenic specific cytotoxic T lymphocytes from peripheral blood. Curr Biol 26: 413-416.

Epperson DE, Margolis DA, McOlash L, Janczah T, Barrett AJ 1999. T cells with graft-versus host (GVHD) or graft-versus-leukemia (GVL) reactivity can be identified by $\mathrm{T}$ cell receptor $\mathrm{V} \beta$ gene spectratyping. Tandem BMT Meeting, Keystone, CO, Abstract p. 38.

Falcão RP, Voltarelli JC, Pestana DR, Simoes BP, Zago MA, Figueiredo MS 1992. A T gamma/delta lymphoproliferative disease with NK activity. Am J Haematol 41: 128-131.

Farahat N, Morilla A, Owusu-Ankomah K, Morilla R, Pinkerton CR, Treleaven JG, Matutes E, Powles RL, Catovsky D 1998. Detection of minimal residual disease in B-lineage acute lymphoblastic leukaemia by quantitative flow cytometry. Br J Haematol 101: 158-164.

Fearnley LF, Whyte LF, Carnoutsos AS, Cook AH, Hart DNJ 1999. Monitoring human blood dendritic cell numbers in normal individuals and in stem cell transplantation. Blood 93: 728-736.

Fritsch G, Stimpfl M, Kurz M, Printz D, Buchinger P, Fischmeister G, Hoecker P, Gardner H 1996. The composition of CD34 subpopulations differ between bone marrow, blood and cord blood. Bone Marrow Transplant 17: 169-178.

Gan OI, Murdoch B, Larochelle A, Dick JE 1997. Differential maintenance of primitive human SCID-repopulating cells, clonogenic precursors, and longterm culture-initiating cells after incubation on human bone marrow stromal cells. Blood 90: 641-650.

Gebauer W, Fallgren-Gebauer E, Corbes C, Schunter F 1996. Quantitation of circulating hematopoietic progenitor cells early after transplantation. Beitr Infusionsther Transfusionsmed 33: 165-169.

Gluckman E, Rocha V, Chastang C for Eurocord-Cord Blood Transplant Group 1998. Cord Blood Hematopoietic Cells: Biology and Transplantation, Education Program Book, American Society of Hematology, Washington, DC, p. 1-14.

Gothot A, van der Loo JCM, Clapp DW, Srour EF 1998. Cell-cycle-related changes in repopulating capacity of human mobilized peripheral blood CD34+ cells in non-obese diabetic/severe combined immune-deficient mice. Blood 92: 2641-2649.

Greiner DL, Shultz LD, Yates J, Appel MC, Perdrizet G, Hesselton RM, Schwitzer I, Beamer WG, Shultz KL, Pelsue SC 1995. Improved engraftment of human spleen cells in NOD/LtSz-scid/scid mice as compared with CB-17-scid/scid mice. Am J Pathol 146: 888-902.

Greiner DL, Hesselton RA, Shultz LD 1998. SCID mouse models of human stem cell engraftment. Stem Cells 16: 166-177.

Greinix HT, Linkesch W, Keil F, Kahls P, Schwarzinger I, Schneider B, Oesterreicher C, Brugger S, Kapiotis S, Lechner K 1994. Early detection of hematopoietic engraftment after bone marrow and peripheral blood stem cell transplantation by highly fluorescent reticulocyte counts. Bone Marrow Transplant 14: 307-313.

Grimley M, Marmer D, Lee S, Filipovich A 1999. Phenotypic analysis of CD4 cells post stem cell transplant (SCT): Prolonged persistence of an activated phenotype and increased proportion of Th2 cells in recipients of matched unrelated donor (MUD) stem cell transplants (SCT). Tandem BMT Meetings, Keystone CO, Abstract p. 8.

Guenechea G, Segovia JC, Abella B, Lamana M, Ramirez M, Regidor C, Fernandez MN, Bueren JA 1999. Delayed engraftment of nonobese diabetic 
severe combined immunodeficient mice transplanted with ex vivo-expanded human CD34+ cord blood cells. Blood 93: 1097-1105.

Guillaume T, Rubinstein DB, Symann M 1998. Immune reconstitution and immunotherapy after autologous hematopoietic stem cell transplantation. Blood 92: 1471-1490.

Guthensonh K, Hummel K, Sputtek A, Cassens U, Kuhnl $\mathrm{P}$ 1996. Storage of peripheral blood cell samples alters flow cytometric CD34+ results. Beitr Infusionsther Transfusionsmed 33: 170-174.

Heitger A, Neu N, Kern H, Panzer-Grumayer ER, Greinix H, Nachbaur D, Niederwieser D, Fink FM 1997. Essential role of the thymus to reconstitute naive (CD45RA+) T-helper cells after human allogeneic bone marrow transplantation. Blood 90: 850857.

Hendriks EC, de Man AJ, van Berkel IC, Stienstra S, de Witte T 1997. Flow cytometric method for the routine follow-up of red cell populations after bone marrow transplantation. Br J Haematol 97: 141-145.

Hogan CJ, Shpall EJ, McNulty O. 1997. Engraftment and development of human CD34+ enriched cells from umbilical cord blood in NOD/LtSz-scid/scid mice. Blood 90: 85-96.

Honda J, Okubo Y, Iamamura Y, Kusaba M, Saruwatari M, Oizumi K 1997. Flow cytometric detection of cytomegalovirus antigen in peripheral blood cells after bone marrow transplantation. Br J Haematol 99: 415-417.

Imbert-Marcille B-M, Robillard M, Poirier A-S, CosteBurel M, Cantarovich D, Milpied N, Billaudel S 1997. Development of a method for direct quantification of cytomegalovirus antigenemia by flow cytometry. J Clin Microbiol 35: 2665-2669.

Jennings CD, Foon KA 1997. Recent advances in flow cytometry: applications to the diagnosis of hematologic malignancy. Blood 90: 2863-92.

Johnsen HE, Rasmussen T, Knudsen LM 1998. CD34+ subset and tumor cell quantitation by flow cytometrystep toward quality assessment of autografts in B cell malignancies. Vox Sang 74 (Suppl. 2): 477-482.

Klein C, Cavazzana-Calvo M, Le Deist F, Jabado N, Benkerrou M, Blanche S, Lisowska-Grospierre B, Griscelli C, Fischer A 1995. Bone marrow transplantation in major histocompatibility complex class II deficiency: a single center study of 19 patients. Blood 85: 580-587.

Kohler M, Dittman J, Legler TJ, Lynen R, Humpe A, Riggert J, Neumeyer H, Pies A, Panzer S, Mayr WR 1996. Flow cytometric detection of platelet-reactive antibodies and application in platelet crossmatching. Transfusion 36: 250-255.

Konikova E, Glasova M, Kusenda J, Babusikova O 1998. Intracellular markers in acute myeloid leukemia diagnosis. Neoplasma 45: 282-291.

Korbling M, Drach J, Champlin RE, Engel H, Huynh L, Kleine HD, Berenson R, Deisseroth AB, Andreeff M 1994. Large-scale preparation of highly purified, frozen/thawed CD34+, HLA-DR- hematopoietic progenitor cells by sequential immunoadsorption (CEPRATE-SC) and fluorescence-activated cell sort- ing: implications for gene transduction and/or transplantation. Bone Marrow Transplant 13: 649-654.

Korbling M, Huh YO, Durett A, Mirza N, Miller P, Engel $\mathrm{H}$, Anderlini P, van Besien K, Andreeff M, Przepiorka D, Deisseroth AB, Champlin RE 1995. Allogeneic blood stem cell transplantation: peripherialization and yield of donor-derived primitive hematopoietic progenitor cells (CD34+Thy-1dim) and lymphoid subsets, and possible predictors of engraftment and graft-versus-host disease. Blood 86: 2842-2848.

Lacerda JF, Ladanyi M, Louie DC, Fernandez JM, Papadopoulos EB, O’Reilly RJ 1996. Human Epstein-Barr virus (EBV)-specific cytotoxic T lymphocytes home preferentially and induce selective regressions of autologous $\mathrm{EBV}$-induced $\mathrm{B}$ cell lymphoproliferation in xenografted CB-17 scid/scid mice. J Exp Med 183: 1215-1228.

Lapidot T, Pflumio F, Doedens M, Murdoch B, Williams DE, Dick JE 1992. Cytokine stimulation of multilineage hematopoiesis from immature human cells engrafted in SCID mice. Science 255: 11371141.

Larochelle A, Vormoor J, Hanenberg H, Wang JC, Bhatia M, Lapidot T, Moritz T, Murdoch B, Xiao XL, Kato I, Williams DA, Dick JE 1996. Identification of primitive human hematopoietic cells capable of repopulating NOD/SCID mouse bone marrow: implications for gene therapy. Nat Med 2: 1329-1337.

Leuner S, Arland M, Kahl C, Jentsch-Ulrich K, Franke A, Hofkes HG 1998. Enumeration of CD34-positive hematopoietic progenitor cells by flow cytometry: comparison of a volumetric assay and the ISHAGE gating strategy. Bone Marrow Transplant 22: 699-706.

Lum LG 1990. Immune recovery after bone marrow transplantation. Hematol Oncol Clin North Am 4: 659-675.

Macedo A, Orfao A, Martinez Z, Vidriales MB, Valverde B, Lopez-Berges MC, San Miguel JF 1995. Immunophenotype of c-kit cells in normal human bone marrow: implications for the detection of minimal residual disease in AML. Br J Haematol 89: 338-341.

Macey MG, McCarthy DA, van Aghtoven A, Newland AC 1997. How should CD34+ cells be analysed? A study of three classes of antibody and five leucocyte preparation procedures. J Immunol Methods 204: 175-188.

Madrigal JA, Cohen SBA, Gluckman E, Charron DJ 1997. Does cord blood transplantation result in lower graft versus host disease? It takes more than two to tango. Human Immunol 56: 1- 5.

Maher GM, Hartman KR 1993. Detection of antineutrophil antibodies by flow cytometry: use of unfixed neutrophils as antigenic targets. J Clin Lab Anal 7: 334-340.

Martin PJ, Hansen JA, Thomas ED 1984. Use of flow microfluorometry in bone marrow transplantation. Ann NY Acad Sci 428: 14-25.

Matsumoto T, Anamoto N, Kondoh T, Kakayama N, Takayanagi T, Tsuji Y 1998. Complete DiGeorge 
syndrome treated by bone marrow transplantation. Bone Marrow Transplant 22: 927-930.

Mavroudis D, Read E, Cottler-Fox M, Couriel D, Molldrem J, Carter C, Yu M, Dunbar C, Barrett J 1996. CD34+ cell dose predicts survival, posttransplant morbidity, and rate of hematologic recovery after allogeneic marrow transplants for hematologic malignancies. Blood 88: 3223-3229.

McCune JM, Namikawa R, Kaneshima H, .Shultz LD, Lieberman M, Weissman IL 1988. The SCID-hu mouse: murine model for the analysis of human hematolymphoid differentiation and function. Science 241: 1632-1639.

Menendez P, Redondo O, Rodriguez A, Lopez-Berges MC, Ercilia G, Lopez A, Duran A, Almeida J, PerzSimon JÁ, San Miguel JF, Gratama JW, Orfao A 1998. Comparison between lyse-and-then-wash and a lyse-non-wash technique for the enumeration of CD34+ hematopoietic progenitor cells. Cytometry 34: 264-271.

Mosier DE, Gulizia RJ, Baird SM, Wilson DB 1988. Transfer of functional human immune system to mice with severe combined immunodeficiency. Nature 335: 256-259.

Miyoshi H, Smith KA, Mosier DE, Verma IM, Torbett BE 1999. HIV vectors efficiently transduce human CD34+ cells that mediate long-term engraftment of NOD/SCID mice. Science 283: 682-686.

Nelson M, Popp H, Forsyth C, Gibson J 1996. Rapid quantitation of mixed red cell populations using flow cytometry. Clin Lab Haematol 18: 207-213.

Nijmeier BA, Willemze R, Falkenburg JHF 1998. An animal model for human adoptive immunotherapy: in vivo elimination of human leukemia by cytotoxic effector cells in NOD/SCID mice. Blood 92 (Suppl. 1): $437 \mathrm{a}$.

Ocqueteau M, Orfao A, Garcia R, San Miguel JF 1996. Detection of monoclonality in bone marrow plasma cells by flow cytometry: limitations for minimal residual disease detection. Br J Haematol 93: 251-252.

Olivero S, Alario T, Ladaique P, Haccoun M, Viens P, Blaise D, Chabannon C 1999. CD34+ cell enumeration in peripheral blood and apheresis samples, using two laboratoriy diagnostic kits or na institutional protocol. Bone Marrow Transplant 23: 387-394.

Orfao A, Garcia-Sanz R, Lopez-Berges MS, BelenVidriales M, Gonzalez M, Caballero MD, San Miguel JF 1994. A new method for the analysis of plasma cell DNA content in multiple myeloma samples using a CD38/propidium iodide double staining technique. Cytometry 17: 332-339.

Peled A, Petit I, Kollet O, Magid M, Ponomaryov T, Byk T, Nagler A, Bem-Hur H, Many A, Shultz L, Lider O, Alon R, Zipori D, Lapidot T 1999. Dependence of human stem cell engraftment and repopulation of NOD/SCID mice on CXCR4. Science 283: 845-848.

Perez-Simon JA, Caballero MD, Corrall M, Nieto MJ, Orfao A, Vasquez L, Amigo ML, Berges C, Gonzalez C, Del Canizzo C, San Miguel JF 1998. Minimal number of circulating CD34+ cells to ensure successfull leukapheresis and engraftment in autolo- gous peripheral blood progenitor cell transplantation. Transfusion 38: 385-391.

Pflumio F, Izac B, Katz A, Schultz LD, Vainchenker W, Coulombel L 1996. Phenotype and function of human hematopoietic cells engrafting immune-deficient CB17-severe combined immunodeficiency mice and non-obese diabetic-severe combined immunodeficiency mice after transplantation of human cord blood mononuclear cells. Blood 88: 3731-3740.

Rasmussen T, Honore L, Johnsen HE 1998. Identification and characterisation of malignant cells using TRPCR on single flow-sorted cells. Med Oncol 15: 96102.

Rebouisoou C, Wijdenes J, Autissier P, Tarte K, Costes V, Liautard J, Rossi J-F, Brochier J, Klein B 1998. A gp130 interleukin-6 transducer-dependent SCID model of human multiple myeloma. Blood 91: 47274737.

Rego EM, Garcia AB, Viana SR, Falcão, RP. 1996. Characterization of acute lymphoblastic leukemia subtypes in Brazilian patients. Leukemia Res 20: 349355.

Rego EM, Garcia AB, Viana SR, Falcão RP 1998a. Agerelated changes of lymphocyte subsets in normal bone marrow biopsies. Cytometry 34: 22-29.

Rego EM, Garcia AB, Falcão RP 1998b. Combined quantification of CD79a, TdT, CD34, CD19 and CD10 densities by quantimetry distinguishes between normal and leukemic B-precursors in the bone marrow. Blood 92 (Suppl. 1): 229a.

Rego EM, Tone LG, Garcia AB, Falcao RP 1999. CD10 and CD19 fluorescence intensity of B cell precursors in normal and leukemic bone marrow. Clinical characterization of CD10+ strong and CD10+ weak common acute lymphoblastic leukemia. Leukemia Res 23: 431-440.

Richardson C, Bank A 1995. Preselection of transduced murine hematopoietic stem cell populations leads to increased long-term stability and expression of the human multiple drug resistance gene. Blood 86 : 2579-2589.

Richter J 1997. Gene transfer to hematopoietic cells- the clinical experience. Eur J Haematol 69: 67-75.

Rill DR, Holliday M, Heslop HE, Krance RA, Kimbrough S, Klingemann H, Brenner MK 1997. Long term transgene expression by human hematopoietic cells in vitro. Blood 90 (Suppl. 1): 405

Rumi C, Rutella S, Bonini S, Bonini S, Lambiase A, Sica S, Puggioni P, Salutari P, Etuk B, Leone G 1998. Immunophenotypic profile of peripheral blood eosinophils in acute graft-vs-host disease. Exp Hematol 26: $170-178$.

Rybka WB, Fontes PA, Rao AS, Winkelstein A, Ricordi C, Ball ED, Starzl TE 1995. Hematopoietic stem cell content of vertebral body marrow used for combined solid organ transplantation. Transplantation 59: 871874.

San Miguel JF, Hernandez MD, Gonzalez M, LopezBerges MC, Caballero MD, Vazquez L, Orfao A, Nieto Mj, Corral M, del Canizo MC 1996. A randomized study comparing the effect of GM-CSF and G-CSF on immune recontitution after autologous 
bone marrow transplantation. Br J Haematol 94: 140147.

San Miguel JF, Martinez A, Macedo A, Vidriales MB, Lopez-Berges C, Gonzalez M, Caballero D, GarciaMarcos MA, Ramos F, Fernandez-Calvo J, Calmuntia MJ, Diaz-Mediavilla J, Orfao 1997. Immunophenotyping investigation of minimal residual disease is a useful approach for predicting relapse in acute myeloid leukemia patients. Blood 90: 2465-2470.

Sasaki DT, Tichenor EH, Lopez F, Combs J, Uchida N, Smith CR, Stokdijk W, Vardanega M, Buckle AM, Chen B. 1995. Development of a clinically applicable high-speed flow cytometer for the isolation of tranplantable human hematopoietic stem cells. $J$ Hemathoter 4: 503-514.

Schots R, van Riet I, Damiaens S, Flament J, Lacor P, Staelens Y, Steenssens L, van Camp B, DeWaele M 1996. The absolute number of circulating CD34+ cells predicts the number of hematopoietic stem cells that can be collected by apheresis. Bone Marrow Transplant 17: 509-515.

Small TN, Papadopoulos EB, Boulad F, Black P, CastroMalaspina H, Childs BH, Collins N, Gillio A, George D, Jakubowski A, Heller G, Fazzari M, Kernan N, MacKinnon S, Szabolcs P, Young JW, O'Reilly RJ 1999. Comparison of immune reconstitution after unrelated and related T-cell depleted bone marrow transplantation: effect of patient age and donor leukocyte infusions. Blood 93: 467-480.

SMSGH- Spanish Multicentric Study Group for Hematopoietic Recovery 1994. Flow cytometric reticulocyte quantification in the evaluation of hematologic recovery. Eur J Haematol 53: 293-297.

Souza MH, Diamond HR, Silva ML, Campos MM, Bouzas LF, Tabak D, Flowers ME, Rumjanek VM 1994. Immunological recovery after bone marrow transplantation for severe aplastic anemia: a Brazilian experience. Eur J Haematol 53: 150-155.

Suzuki R, Yamamoto K, Seto M, Kagami Y, Ogura M, Yatabe Y, Suchi T, Kodera Y, Morishima Y, Takahashi T, Saito H, Ueda R, Nakamura S 1997. CD7+ and CD56+ myeloid/natural killer cell precursor acute leukemia: a distinct hematolymphoid disease entity. Blood 90: 2417-2428.

Tabernero MD, San Miguel JF, Garcia JL, Garcia-Isidoro M, Wiegant J, Ciudad J, Gonzalez M, Rios A, Raap A, Orfao A 1995. Clinical, biological, and immunophenotypical characteristics of B-cell chronic lymphocytic leukemia with trisomy 12 by fluorescence in situ hybridization. Cytometry 22: 217-222.

Talmadge JE, Reed E, Ino K, Kessinger A, Kuszynski C, Heimann D, Varney M, Jackson J, Vose JM, Bierman PJ 1997. Rapid immunologic reconstitution following transplantation with mobilized peripheral blood stem cells as compared to bone marrow. Bone Marrow Transplant 19: 161-72.

Tarantolo SR, Bishop MR, Lynch JC, Davis JR, Pirruccello SJ, Bierman PJ, Pavletic ZS, Armitage JO, Jessinger A, Gross TG 1998. Effect of G-CSF mobilization on type 1 and type $2 \mathrm{~T}$-cells and corre- lation to acute graft-versus-host disease (GvHD). Blood 92 (Suppl. 1): 722a.

Thomas C, Le Deist F, Cavazzana-Calvo M, Benkerrou M, Haddad E, Blanche S, Hartman W, Friedrich W, Fischer A 1995. Results of allogeneic bone marrow transplantation in patients with leukocyte adhesion deficiency. Blood 86: 1629-1635.

Thomas ED 1994. The Nobel Lectures in Immunology. The Nobel Prize for Physiology or Medicine, 1990. Bone Marrow Transplantation- past, present and future. Scand J Immunol 39: 339-45.

Trenschel R, Bernier M, Delforge A, Massy M, Lebeau DHE, Maerevoet M, Badjou R, Stryckmans P, Bron D 1998. Myeloid and lymphoid recovery following allogeneic bone marrow transplantation: a comparative study between related, unrelated bone marrow and allogeneic peripheral stem cell transplantation. Leuk Lymphoma 30: 325-352.

Uchida N, Coombs J, Chen S, Zanjani E, Hoffman R, Tsukamoto A 1996. Primitive human hematopoietic cells displaying differential eflux of the rhodamine 123 dye have distinct biologic activities. Blood 88 : 1297-1305.

Uckun FM 1996. Severe combined immunodeficient mouse models of human leukemia. Blood 88: 11351146.

Van der Loo JCM, Hanenberg H, Cooper RJ, Luo F-Y, Lazaridis EN, Williams DA 1998. Nonobese diabetic/severe combined immunodeficiency (NOD/ SCID) mouse as a model system to study the engraftment and mobilization of human peripheral blood stem cells. Blood 92: 2556-2570.

Van Tol MJ, Langlois van den Bergh R, Mesker W, Ouwerkerk-van Velzen MC, Vossen JM, Tanke HJ 1998. Simultaneous detection of X and Y chromosomes by two-colour fluorescence in situ hybridization in combination with immunophenotyping of single cells to document chimaerism after sex-mismatched bone marrow transplantation. Bone Marrow Transplant 21: 497-503.

Vigorito AC, Azevedo WM, Marques JFC, Azevedo AM, Eid KAB, Aranha FJP, Lorand-Metze I, Oliveira GB, Correa MEP, Reis ARC, Miranda ECM, Souza CA 1998. A randomized, prospective comparison of allogeneic bone marrow and peripheral blood progenitor cell transplantation in the treatment of hematological malignancies. Bone Marrow Transplant 22: 1145-1151.

Voltarelli JC, Stites DP 1986. Immunological monitoring of bone marrow transplantation. Diagn Immunol 4: 171-193.

Voltarelli JC, Przepiorka D, Sandell ML, Johnson GA, Kopecky K, Martin PJ, Torok-Storb B 1989. CD8+/ DR+/CD25- T lymphocytes associated with marrow graft failure. Bone Marrow Transplant 4: 647-652.

Voltarelli JC, Corpuz S, Martin PJ 1990. In vitro comparison of two methods of $\mathrm{T}$ cell depletion associated with different rates of graft failure after allogeneic marrow transplantation. Bone Marrow Transplant 6: 419-423.

Warren EH, Bonnet D, Greenberg PD, Dick JE, Riddell SR 1997. CD8+ minor histocompatibility antigen- 
specific CTL prevent AML engraftment in NOD/ SCID mice. Blood 90 (Suppl. 1): 395a

Wells DA, Hall MC, Shulman HM, Loken MR 1998a.

Occult B cell malignancies can be detected by threecolor flow cytometry in patients with cytopenia. Leukemia 12: 2015-23.

Wells DA, Sale GE, Shulman HM, Myerson D, Bryant EM, Gooley T, Loken MR 1998b. Multidimensional flow cytometry can differentiate leukemic from normal lymphoblasts and myeloblasts after chemotherapy and bone marrow transplantation. Am J Clin Pathol 110: 84-94.

Yamada M, Ohtsu M, Kobayashi I, Kawamura N,
Kobayashi K, Ariga T, Sakiyama Y, Nelson DL, Tsuruta S, Anakura M, Ishikawa M 1999. Flow cytometric analysis of Wiskott-Aldrich syndrome (WAS) protein in lymphocytes from WAS patients and their family carriers. Blood 93: 756-759.

Yurasov S, Kollman TR, Kim A, Raker CA, Hachamovitch M, Wong-Staal F, Goldstein H 1997. Severe combined immunodeficient mice engrafted with human T cells, B cells and myeloid cells after transplantation with human fetal bone marrow or liver cells and implanted with human fetal thymus: a model for studying human gene therapy. Blood 89: 1800-1810. 